\title{
Geoengineering governance-by-default: an Earth System Governance perspective
}

\author{
Anita Talberg ${ }^{1}$, Peter Christoff ${ }^{2},{\text { Sebastian } \text { Thomas }^{3} \text {, David Karoly }}^{4}$ \\ ${ }^{1}$ Australian-German Climate and Energy College, University of Melbourne \\ ${ }^{2}$ Department of Geography and Resource Management, University of Melbourne \\ ${ }^{3}$ Sustainability Science Lab and School of Ecosystem and Forest Sciences, University of Melbourne \\ 4. School of Earth Sciences and Australian-German Climate and Energy College, University of Melbourne
}

Corresponding author: Anita Talberg, email: anita.talberg@unimelb.edu.au

\begin{abstract}
:
Geoengineering - the deliberate interference in the climate system to affect global warming-could have significant global environmental and social implications. How to shape formal geoengineering governance mechanisms is an issue of debate. This paper describes and analyses the geoengineering governance landscape that has developed in the absence of explicit geoengineering regulation. An Earth Systems Governance perspective provides insight into the formation of norms resulting from an overlap in international treaties and from the actions of engaged non-state agents. Specifically, the paper explores the instruments and actors having effect in existing formal and informal geoengineering governance mechanisms. It finds that geoengineering is subject to a form of 'governance-by-default'. This is due to a situation in which state actors have not resolved the tension between two legal norms: that of 'caution' and that of 'harm minimisation'. This governance-bydefault is characterised by uneven regulation from existing multilateral agreements established for other purposes, an absence of regulation specifically focused on geoengineering, guidance from an international ambition to hold global average warming below two-degrees Celsius and to achieve net-zero emissions in the second half of the century, and strong normative engagement by the research community. Governance-bydefault is likely to be a stopgap development until more enduring and focused governance emerges.
\end{abstract}

Keywords:

Climate change; climate engineering; solar radiation management; carbon dioxide removal; international law

\section{Acknowledgements:}

A.T. receives a Strategic Australian Postgraduate Award scholarship. A.T. would like to acknowledge input from Kerryn Brent, Ellycia Harrould-Kolieb and Kate Dooley that informed the shape of the final paper.

\section{Author Contributions:}

A.T. performed the research and analysis and produced all draft versions of the paper with guidance and feedback from S.T., P.C., and D.K.

\section{Conflicts of Interest:}

The authors declare no conflict of interest.

\section{Geoengineering governance-by-default: an Earth System Governance perspective}

\section{Introduction}

Current attempts to reduce greenhouse gas emissions remain insufficient to hold global average warming below $2^{\circ}$ Celsius above pre-industrial levels (Le Quéré et al. 2015). Consequently other means of restraining warming, referred to as climate engineering or geoengineering, are being proposed (Crutzen 2006; Keith 2013). Advocates contend that such ideas should be developed as additional measures for the climate change policy toolbox 
(Keith 2000) and interest from research communities is growing rapidly (Oldham et al. 2014). However, some geoengineering techniques and technologies raise concerns relating to their potential transnational environmental and social impacts (Robock 2008); 'geoengineering could be a "cure worse than the disease"' (Schneider 1996, p. 299).

This paper presents an analysis of international geoengineering governance, informed by a survey of existing regulatory instruments and recent controversial geoengineering activities, and a qualitative evaluation of the governance landscape that has resulted. It evaluates the status quo of geoengineering governance, which has been described as a 'patchwork' of regulation provided by multilateral agreements designed for other purposes (Larson 2016). In this paper, we take environmental governance to be a complex web of governmental and nongovernmental rules and norms that shape the behaviours of actors and organisations seeking to navigate environmental change (Biermann et al. 2010).

The paper sets its discussion of geoengineering in the broader context of Earth System Governance (ESG) (Biermann et al. 2010) by addressing three specific questions: (1) what existing governance instruments are relevant to geoengineering; (2) who are the principal actors currently engaged in geoengineering; (3) what are the features and likely outcomes of geoengineering governance?

The paper consists of five sections. Following a brief introduction to geoengineering technologies, governance issues and risks, and an overview of ESG, the second section presents the research framework. The third section reviews the geoengineering governance landscape; the fourth highlights the norms that define that governance landscape. The fifth section argues that a form of governance-by-default prevails, and explores the implications. The final section concludes and identifies future research needs.

\subsection{Geoengineering technologies and risks}

The Royal Society defines geoengineering as “...deliberate large-scale intervention in the Earth's climate system, in order to moderate global warming” (Royal Society 2009, p. ix). Geoengineering methods or technologies are divided into two overarching types: Carbon Dioxide Removal (CDR), which aims to reduce atmospheric carbon dioxide levels, and Solar Radiation Management (SRM), which aims to reflect some of the sun's heat away from the Earth.

CDR geoengineering techniques are intended to draw carbon dioxide from the atmosphere, but do not affect greenhouse gas emissions. Examples include large-scale reafforestation, bioenergy with carbon capture and storage (BECCS), and machines that 'suck' carbon from the air. To have a long-term effect, many of these techniques rely on geological storage of the extracted carbon. Other examples include processes to enhance the ocean's biological capacity to draw down and sequester carbon in the deeper ocean. These include ocean fertilisation using iron or other nutrients, mechanical promotion of circulation of deeper 
nutrient-rich waters to the surface, and ocean liming to reduce ocean acidity and increase carbon removal (Lenton 2014). ${ }^{1}$

SRM techniques are intended to limit warming by intercepting solar radiation before it reaches the Earth's surface. Proposed methods involve atmospheric measures such as injecting particles into the stratosphere to deflect sunlight or spraying salt particles into lowlying marine clouds to make them whiter and more reflective; terrestrial measures such as covering the ocean or deserts with reflective material; and space-based approaches such as placing sunshades or mirrors in orbit (Vaughan and Lenton 2011).

Modelling suggests that SRM could reduce the differences in climates caused by elevated greenhouse gas concentrations (IPCC 2013), although with regional variations (Kravitz et al. 2014). Should greenhouse gas concentrations reach dangerous levels, some SRM methods could, in theory, be deployed quickly to bring temperatures down - an important consideration for those communities and species most vulnerable to rising temperatures. CDR offers the capacity to deliver negative emissions, which climate models suggest will be necessary to hold global average temperatures within $2^{\circ}$ Celsius in the absence of effective SRM (IPCC 2013).

Nonetheless, the science of many geoengineering methods is complex and uncertain. The deployment of global geoengineering methods, or the application of local geoengineering methods at a scale needed to have global effect, as well as regionally disparate impacts is likely to have potentially adverse climatic and/or environmental effects (National Research Council 2015a, 2015b). Associated potential environmental and human impacts, and their possible uneven regional distribution, suggest that any prospect of geoengineering warrants measured consideration and debate at multiple jurisdictional scales.

Many geoengineering techniques pose governance issues common to other transboundary environmental problems, including the ethical dilemmas and the challenge of achieving harmony among competing political institutions, worldviews and values that confront attempts to govern the global commons. However, geoengineering technologies also face distinctive issues, such as the problem of 'moral hazard' posed by these technologies possibly becoming distractions from efforts of global mitigation and adaptation (Reynolds 2014).

Reports from bodies such as the US National Research Council and the UK Royal Society, and various other scientific and technical papers, contend that further research may reduce uncertainty about potential impacts and pave the way for robust decision-making around deployment and governance (Keith and MacMartin 2015; National Research Council 2015a, 2015b; Royal Society 2009). Many legal scholars and social scientists argue that governance should be developed alongside or even before further research into implementation, because of the moral and justice issues that can arise from some geoengineering technologies, and the uneven distribution of risks (Brent et al. 2016; Lin 2015). Despite these concerns, no binding international laws currently in force explicitly regulate geoengineering, in part because ' $[\mathrm{n}] \mathrm{o}$

\footnotetext{
${ }^{1}$ There is no consensus in the geoengineering literature whether large-scale biochar, which is plant-based charcoal used to increase soil carbon retention, or large-scale afforestation should also be included in the definition of CDR.
} 
binding definition of climate engineering exists under international law' (Rickels et al. 2011, p. 104).

\subsection{Earth System Governance}

Geoengineering involves large-scale changes to the global climate and thus cannot be considered in isolation from associated changes in ecosystems and society. The research framework developed by Biermann et al. (2010) to consider ESG integrates research into natural and human processes with the study of regulatory and management systems. It is thus well suited to the interrogation of geoengineering governance and has therefore been used in this study.

To untangle the multiple elements of governance, the ESG framework defines specific analytical problem structures and cross-cutting themes. ESG is described as the "interrelated and increasingly integrated system of formal and informal rules, rule-making systems, and actor-networks at all levels of human society (from local to global) that are set up to steer societies towards preventing, mitigating, and adapting to global and local environmental change and, in particular, earth system transformation, within the normative context of sustainable development" (Biermann et al. 2010, p. 279). The terms 'steer' and 'sustainable development' imply that environmental governance is purposive, guided by the values and goals of sustainable development, widely accepted as first established by the Brundtland Report as "development that meets the needs of the present without compromising the ability of future generations to meet their own needs" (WCED 1987) and since articulated practically in the United Nations' Sustainable Development Goals (UN General Assembly 2015).

The ESG framework describes five focal points for analytical attention. The first focuses on types and systems of governance architecture, and the second on the roles of agents or actors at different levels in governing Earth systems. The third highlights the importance of the systemic adaptiveness of governance systems to the needs of environmental change. The fourth focuses on the extent and means of accountability and legitimacy (of and) for governance mechanisms. The fifth focuses on defining and addressing questions of fair allocation and access regarding benefits, risks, and responsibilities in environmental change. The framework also identifies four fundamental elements that help constitute these focal points: power, knowledge, norms, and scale (Biermann et al. 2010).

\section{Method}

This study proceeded in two steps. It first described geoengineering's international governance landscape using the first two analytical focal points of the ESG framework relating to international governance architecture, and actors (or agency). It primarily analysed the architecture of governance; consideration of the role of actors provided additional insight and context. It then used the concept of norms to explore the resulting governance landscape (Figure 1).

Of the five elements of the ESG framework, architecture and agency were chosen because they provide, by their natures, the means to identify and sketch the elements of a geoengineering governance landscape. Whereas accountability, adaptability, and allocation are measures of the features of governance or the governance problem, architecture and 
actors can be regarded as pure concepts and irreducible system elements. Consideration of norms ahead of the other constitutive drivers proposed by the ESG approach comes from our view that normative considerations underpin and explicitly or implicitly guide the choices inherent in the three other elements (power, knowledge and scale).

\subsection{Governance architecture}

A range of concepts and theories may be deployed to describe and analyse the structures of international governance. For instance, structures of governance may be analysed using regime theory: regimes are commonly understood to be a cluster of "principles, norms, rules, and decision-making procedures around which actor expectations converge in a given issuearea" (Krasner 1983, p. 1), while a regime complex consists of multiple overlapping regimes governing an issue-area (Keohane and Victor 2011). By contrast, here we employ the concept of 'governance architecture' - or sometimes more succinctly, 'architecture' - to refer more narrowly to government-established frameworks or structures (Biermann et al. 2009; Pattberg et al. 2014) and to suggest an institutional framework deliberately designed and constructed (although this can be taken too far, as is discussed below in relation to agency). In other words, the concept is used here, analytically, to distinguish deliberate, formal and government-based mechanisms from informal and non-government ones.

The governance architecture of geoengineering was identified through a review of international agreements (treaties, conventions and their protocols) recorded in two key treaty databases: the United Nations Treaty Collection (UNTC) and the Environmental Treaties and Resource Indicators (ENTRI) database. Both were searched for the terms 'environment', 'climate change', 'biodiversity', 'biological diversity', 'ocean', 'sea', 'atmosphere', 'air space' and 'outer space'-terms selected to reflect the land-based, oceanic, atmospheric, and space-based nature of geoengineering technologies and the arenas of their potential effects. The scope of the review was restricted to multilateral agreements with more than 50 members. While inclusion of bilateral or minilateral agreements would provide more detailed picture, it is believed not to offer a significantly different picture.

\subsection{Actors and agency}

A review of international treaties that focuses only on the outcomes and frameworks of governance formally agreed among states provides only an incomplete and somewhat static picture of geoengineering governance. Therefore, this study also examined the role of both state and non-state actors and agents relevant to international governance of geoengineering to provide additional depth and context the analysis.

Agency can be defined as the "capacity of individual and collective actors to change the course of events or the outcome of processes" (Pattberg and Stripple 2008, pp. 373-4) and agents can be described as those 'authoritative actors' who directly or indirectly influence the decisions of others (Dellas et al. 2011). In this study, we initially use a more expansive approach, by considering actors without necessarily attributing agency. The question of 
whether these actors have become agents is addressed in the subsequent discussion of norms and governance. ${ }^{2}$

Here, actors were identified through their geoengineering governance-related actions, which include participation in:

- the production of publications (from academic articles to media statements) that frame the governance of geoengineering,

- the creation of key laws (including lobbying for, input into, drafting or passing of laws),

- involvement in key projects or experiments (both involvement in and oversight of),

- establishment of epistemic networks involved in discussions of geoengineering (through workshops, as collaborative ventures between individuals, communities or nations), and

- funding any of the above activities (with implicit or explicit decisions being made about the legitimacy of geoengineering).

Instances of these actions were collected from reviews of the geoengineering academic and grey literature and from media reports. Specifically, the terms 'geoengineering' and 'climate engineering' were used with keywords from the above list in a Google search and then a Web of Science search. Actors were categorised into seven groups: intergovernmental organisations (IGOs), States, academia, non-governmental organisations (NGOs), philanthropy, commercial interests, media, and ad hoc geoengineering groupings. The last category refers to networks of individuals that have formed specifically around geoengineering, but were not captured by the other categories.

\subsection{Norms}

This study also analysed the norms structuring this governance landscape. Norms are widely understood to be social standards that "channel and regularize behaviour...often limit[ing] the range of choice and constrain[ing] actions" (Finnemore and Sikkink 1998, p. 984). Such standards can be articulated formally through laws and regulations or through informal cultural mechanisms and related codes of practice. Norms formally deployed by states and relating to geoengineering were identified through an analysis of relevant international agreements. Norms developed and established by non-government players were identified by reviewing commonalities and deviances in actors' behaviour.

Figure 1: The research framework and process

INSERT FIGURE 1 SOMEWHERE AROUND HERE

\section{Elements of geoengineering governance}

\footnotetext{
${ }^{2}$ As it is not clear where to draw the line in considering which actors become agents and which do not, Dellas et al. (2011) recommend cataloguing actors involved in an issue area and then clarifying which of those actors has become authoritative, highlighting that "the source of authority underpinning agency may be found in agents' capacity to be more responsive and participatory than public institutions, in the unresponsiveness of state bureaucracies, in effective and efficient problem-solving and finally in their ability to gain the recognition of key audiences as innovative and successful problem-solvers" (2011, p. 93).
} 


\subsection{Architecture}

The review of international agreements (treaties, conventions and their protocols) that might contribute to governance of geoengineering identified 11 principal instruments, most with related Protocols or Agreements or other treaties part of a collection of treaties (i.e. the Antarctic Treaty System (ATS) and the collection of outer space treaties (OSTs) are each counted as having one principal instrument) (Table 1).

\section{INSERT TABLE 1 SOMEWHERE AROUND HERE}

International legal scholars distinguish between 'hard' law, which is binding or enforceable, with clear obligations and delegations, and 'soft' law, which lacks some or all of these elements (Abbott and Snidal 2000; Chinkin 1989). No hard international law currently in force explicitly mentions geoengineering or a geoengineering technology (Bodle et al. 2014; Rickels et al. 2011). However, as Table 1 indicates, multiple multilateral agreements contain 'hard' and 'soft' law elements that contribute to the governance of geoengineering technologies.

Three treaties have sought to address geoengineering or a geoengineering technology directly, albeit not necessarily explicitly using those terms. The Convention on the Prohibition of Military or Any Other Hostile Use of Environmental Modification Techniques (ENMOD) treaty from 1978, which was designed with weather modification in mind, prohibits environmental modification for the purposes of warfare and therefore restricts geoengineering only if the act was hostile, destructive, and with widespread, long-lasting or severe effects (Bodansky 2011; Virgoe 2009).

The Conference of the Parties (COP) to the Convention on Biological Diversity (CBD) passed a decision in 2010 that

...no climate-related geo-engineering activities that may affect biodiversity take place, until there is an adequate scientific basis on which to justify such activities and appropriate consideration of the associated risks for the environment and biodiversity and associated social, economic and cultural impacts, with the exception of small scale scientific research studies that would be conducted in a controlled setting in accordance with Article 3 of the Convention, and only if they are justified by the need to gather specific scientific data and are subject to a thorough prior assessment of the potential impacts on the environment (CBD COP decision X/33 8(w))

This has been interpreted by some commentators as a general moratorium on geoengineering (Tollefson 2010; Walsh 2010), but the legal status of the Convention and the language of the text fail to define any legal obligation (Scott 2012). The decision supports small-scale scientific research into geoengineering (CBD 2010). A subsequent CBD COP decision, in 2016, called for 'more transdisciplinary research and sharing of knowledge among appropriate institutions' (CBD 2016).

The Convention on the Prevention of Marine Pollution by Dumping of Wastes and Other Matter (the London Convention or LC) and its protocol (the London Protocol) (the LP) have provided a platform for legal debate regarding marine geoengineering. Amendments passed under the LP create an updateable list of marine geoengineering methods than can be either banned or limited to legitimate scientific research — currently only ocean fertilization is listed. 
These amendments have not come into force (and are therefore in this study considered 'soft' law).

In total, three Conventions regulating oceans are relevant to geoengineering technologies with marine elements (Table 1). Two regulating the atmosphere are relevant to geoengineering technologies with atmospheric elements (although the Convention on Long Range Transboundary Air Pollution (CLRTAP) with a membership of 51 nations just met the criteria for inclusion). The outer space treaties regulate outer space and are relevant to spacebased technologies. Another five Conventions are likely to apply broadly to many geoengineering technologies.

In its aim to reduce the effects of climate change, protect the environment and benefit humanity, geoengineering (or at least further research into geoengineering) appears to be supported by many of these instruments: the UN Convention on the Law of the Sea (UNCLOS), the CBD, the UN Convention to Combat Desertification, the OSTs, the ENMOD Convention, the United Nations Framework Convention on Climate Change (UNFCCC), the Vienna Convention and the ATS.

The UNFCCC and its 2015 Paris Agreement deserve special mention. The UNFCCC explicitly supports climate change policies that are least-cost and establishes that "lack of full scientific certainty should not be used as a reason for postponing such measures" (UNFCCC art 3). According to some scholars, this could support any geoengineering scheme that might be considered 'least-cost' (Virgoe 2009). The UNFCCC also urges all Parties to "promote and cooperate in the conservation and enhancement, as appropriate, of sinks and reservoirs [...] including biomass, forests and oceans as well as other terrestrial, coastal and marine ecosystems" (UNFCCC art 4(d)). This acknowledges the importance of conserving and enhancing biological sinks. The question is whether a definition is needed to distinguish CDR from other activities that enhance biological sinks to balance greenhouse gas emissions. It can be considered that BECCS, large-scale biochar and large-scale afforestation are all possible CDR measures and therefore Article 4 could be seen as supportive of those. The 2015 Paris Agreement establishes a goal of holding average global warming well below two-degrees Celsius and reaching net zero gigatonnes of emissions in the second half of the century. By urging its parties "to achieve a balance between anthropogenic emissions by sources and removals by sinks of greenhouse" (Paris Agreement art 4), it ostensibly supports geoengineering, including CDR and, potentially, indirectly, SRM.

All 11 treaties in some way restrict how or where geoengineering or specific technologies might be used. For example, the Paris Agreement emphasises the need to ensure that action is taken in a manner that "does not threaten food production" (Paris Agreement art 2). The outer space treaties emphasise that space-based SRM schemes would need to have "due regard" for other Parties to the Treaty (Outer Space Treaty Art IX), and liability would arise if it could be established that a space object caused damage to human health or property of a State (Space Liability Convention Art II) (Humphreys 2011; Rickels et al. 2011).

Finally, although not expressly noted in Table 1, geoengineering is also governed by customary international law, such as the no-harm rule and the duty of due diligence to prevent transboundary harm, of which a duty to conduct an environmental impact assessment is a component (Brent et al. 2015; Scott 2012). 


\subsection{Actors}

International treaties provide only one, albeit very important, contribution to the architecture of international geoengineering governance. To contextualise this picture, here we look at the additional role of state and non-state actors.

Geoengineering governance has been expressly considered only in the United States (US), the United Kingdom (UK), and Germany. The European Union, a supranational entity, can be added to that list because it acts as a unified entity in many international fora. In Canada, Norway, Australia, Russia, China, and India, geoengineering has been recognised as an issue by some government bodies, but has not become a matter of national priority. No country has an official policy on geoengineering, nor has any government department been relegated responsibility.

Several governments have supported further research. For instance, in 2009, the German government supported an ocean fertilisation scientific research project in collaboration with Indian scientists, arguing that the experiment was small-scale and therefore did not conflict with international treaty decisions. No environmental impact assessment of the project was undertaken, despite such a requirement being included in many forms of 'soft' and 'hard' international law identified in the previous section. In 2012, an ocean fertilisation project was undertaken by a commercial entity off the coast of Canada, and has prompted the Canadian government to investigate the matter.

At the intergovernmental level, the UN General Assembly, the UN Educational, Scientific and Cultural Organization (UNESCO) and its Intergovernmental Oceanographic Commission (IOC), the Intergovernmental Panel on Climate Change (IPCC), and the World Meteorological Organisation are amongst the organisations that have shown some interest in geoengineering. A common feature of their positions is support for further research (especially collaboratively) and a precautionary view of ocean fertilisation.

Geoengineering debate and agenda-setting are strongly driven by academics, including natural scientists, engineers, legal scholars, economists, and philosophers, mostly from English-speaking Western countries, particularly in the Northern Hemisphere (Belter and Seidel 2013). These academics seem to have clustered into groups constituting and advocating different orientations for geoengineering governance. While all urge a focus on mitigation before consideration of geoengineering, some strongly support further research while others are more wary of this on ethical grounds. There are, nonetheless, a number of ongoing geoengineering experiments, both laboratory-based and field-based (Keith et al. 2014)

A limited but growing grey literature (mainly emanating from multi-disciplinary academic discussions) adds to this academic work. For example, the Oxford Principles - a group of proposed guiding principles for geoengineering governance produced by a group of academics (Rayner et al. 2013) - have been influential among academics, NGOs, intergovernmental and state actors (Asilomar Scientific Organizing Committee 2010; CBD Secretariat 2012; iagp.ac.uk 2015; NERC 2016). For instance, one outdoor SRM experiment, known as the Stratospheric Particle Injection for Climate Engineering (SPICE) project, was designed to investigate engineering feasibility of stratospheric aerosol injection and included a trial of pumping water through a pipe kept aloft by tethered balloons (Cressey 2012). The 
field trial was ultimately abandoned, with the leader of the SPICE project citing the Oxford Principles in justifying his group's decision to cancel the experiment (Watson 2012).

Although NGO interest in geoengineering is limited (Nicholson and Thompson 2015), Rickels et al. 2011) and lacks cohesion, large transnational NGOs have been important in terms of agenda-setting. For instance, Greenpeace International and the World Conservation Union were instrumental in raising marine geoengineering onto the LC/LP agenda (Greenpeace International 2007; IUCN 2007).

Some non-negligible funds have been disbursed by philanthropists to further geoengineering research. There has been little commercial interest other than a limited number of patent applications, and here commercial interest has been in CDR only. One American entrepreneur, Russ George, through a series of ocean fertilisation projects, is responsible for triggering debate over geoengineering at the international level (through the LC/LP) and at the state-level (Canadian investigation into the ocean fertilisation project incident). ${ }^{3}$

\section{The role of norms in international geoengineering governance}

By what norms is geoengineering governed? Two types of norms are considered here: legal and social. ${ }^{4}$

\subsection{Legal norms}

Legal norms are those based in laws (and associated regulations) that encourage or require, or discourage, certain behaviours. We confine our attention to legal norms that manifest in the international treaties listed in Table 1. Analysis of national laws is beyond the scope of this study, but would add value as national laws implementing international treaties provide additional indications of the effectiveness of a legal norm.

Two overarching legal norms can be distinguished. The first is that of 'precaution'. Without delving into the complex and ongoing debate on the various forms and meanings of the precaution principle (of which there are many (Elliott 2010)), we define this norm as requiring inaction until potential significant dangers and consequences are better understood (while recognising that the principle also encourages beneficial action even if scientific knowledge about outcomes is incomplete). In the case of geoengineering, at present this

\footnotetext{
${ }^{3}$ There is another discussion to be had about the informal influence of actors at the national level. The public debate around geoengineering is heterogeneous and complex, as evidenced through different media portrayals and the perspectives underlying popular literature.

Networks of highly active conspiracy theorists have developed. A survey of 3000 individuals across the US, Canada and the UK found that $2.6 \%$ of those questioned completely believe that there are covert government activities spraying atmospheric contaminants and 14\% partly believe it (Mercer et al. 2011). Anecdotal evidence suggests that many individuals who believe in these 'chemtrail' conspiracies attend academic conferences, and there are reports of such people having abused and threatened geoengineering researchers (Cairns 2014). The views of these groups were noted by the US Congress during committee hearings on geoengineering (House Hearing 111 Congress 2010).

${ }^{4}$ Moral norms are not considered here, as this would require insight into actors' convictions, which may not be reflected by their actions.
} 
principle disallows or discourages the deployment of potentially significant and irreversibly harmful technologies or techniques, certainly in the absence of guidance from and limitation by relevant laws.

This is evidenced in the soft law of the LC/LP 2008 resolution that no ocean fertilisation take place until "a global, transparent and effective control and regulatory mechanism is in place for these activities" (LC/LP 2008), and that of the CBD COP decision calling for no geoengineering activities with potential biodiversity impacts to take place "in the absence of science based, global, transparent and effective control and regulatory mechanisms" (CBD COP 2010, para. 8(w)).

The second legal norm is that of 'harm minimisation'. Many of the treaties in Table 1 include environmental and social safeguard clauses, and these concepts are also enacted through common and customary law. For instance, CBD decision in 2010 require that research include "prior assessment of the potential impacts on the environment" (Convention on Biological Diversity 2010, para. 8(w)), while the adopted (but not in force) LP amendment resolution LP.4(8) outlines six pages of an assessment framework that must be followed before legitimate scientific research into ocean fertilisation may be considered (LC/LP 2013). 'Harm minimisation' drives decisions and actions, and supports research, that are in aid of preserving the environment and of benefiting mankind. In relation to geoengineering, which aims to reduce the harms associated with climate change, it legitimises research. The decisions of both the LC/LP and the CBD deliberately exclude "small scale scientific research" from their restrictive rulings (CBD COP 2010; LC/LP 2008). This norm is also overarchingly (although implicitly) articulated by the UNFCCC's Paris Agreement, which confirms a $2^{\circ}$ Celsius warming limit and establishes the goal of reaching net zero gigatonnes of emissions in the second half of the century - the ' $2 \mathrm{C} \& 0 \mathrm{Gt}$ ' target.

Legal norms are effective insomuch as they are legitimately enforceable and enforced, yet enforcement mechanisms of international law are limited. As a result, not all legal norms are fully observed. The precautionary principle here serves as a norm requiring inaction until consequences are better understood. It is difficult to observe conformity to a norm when this is expressed through inaction, but the effect of the norm can be observed in states' responses (if any) to cases of nonconformity. So, for example, how the Canadian Government has responded to the 2012 ocean fertilisation project off the coast of British Columbia is a test of the depth and strength of international support for this norm. Although there was discussion of the experiment at subsequent meetings of the CBD, there is no evidence that other states heavily condemned the experiment or have pressured the Canadian government to react in any specific way. It would thus be premature to assert whether this norm has a strong element of enforceable obligation. By contrast, the second norm - 'harm minimisation' - is a norm that emphasises beneficial action, such as for example, active research agendas.

These two norms' relationship to each other is not straightforward. The precautionary principle prohibits both taking action without sufficient insight into the consequences, and using the excuse of insufficient scientific understanding for inaction where action might be beneficial. In contrast, harm minimisation requires action. Under conditions of relative certainty both can be complementary in that one cannot proceed to minimise some harm while causing more than is minimised. However, while there is uncertainty on the impacts of 
both action and inaction, the relationship between the two can seem contradictory: one enables while the other disables.

The tension between the two can be resolved if research and deployment can be cleanly separated. 'Precaution' defers deployment until rigorous research can assure us that 'harm minimisation' is the dominant outcome. Yet research and deployment cannot be clearly divorced from each other for some geoengineering technologies, either physically or from a governance perspective. Where geoengineering methods are intended for non-encapsulated systems, such as the ocean or the atmosphere, testing, monitoring and data collection need to take place over a large area and a long term, maybe a decade (Robock et al. 2010), for detection and attribution of the effects of experimental inputs against the background of other natural variations. For these techniques, some types of fieldwork could be safely undertaken (such as small-scale experiments designed to explore limited and bounded hypotheses), but often there is no clear line between meaningful field-testing of geoengineering and deployment (Keith et al. 2010). There is also the potential for a financial or technological slippery slope from research to deployment (Oldham et al. 2014).

\subsection{Social norms}

Social norms are cultural codes that define what is considered to be acceptable behaviour and what is considered to go against that standard (Finnemore and Sikkink 1998). While social norms may find 'hard' forms of expression (in formal, state-sanctioned laws and rules), here we will concentrate on 'soft' or more informal codes and practices. Actors within a reference group could establish and conform to a social norm for different individual reasons.

Therefore, in this study we do not delve into actors' expectations or beliefs, we limit the study to observations of behaviour.

Intergovernmental organisations, through their reviews and publications, play both norm- and agenda-setting roles. The increasing number of wide-ranging and comprehensive publications from these organisations normalises geoengineering research that is both collaborative and publicly available, while the conclusions and key messages of these reports establish the ongoing agenda. The key messages from these reports are that the science behind many of the more controversial geoengineering proposals is highly uncertain and that ocean fertilisation is likely inefficient and risky (see for example IPCC 2013; Wallace et al. 2010).

A limited number of governments is involved in any discussion of geoengineering and there is a lack of regulation and discussion of the topic from even those nations. However, both the US and the UK have urged international bodies to consider regulating geoengineering (DECC 2010; US 2007) and those states that have been in any way involved with discussing geoengineering have mostly supported or funded further research. The actions of state actors suggest that governments have not been able to resolve the tension between the legal norms of 'precaution' and 'harm minimisation'. This results in state actors being either disengaged or adopting a 'wait and see' response while supporting further academic research in the context of the ' $2 \mathrm{C} \& 0 \mathrm{Gt}$ ' target.

Academia cannot be described as one homogenous community, and it is difficult to discern consistent behaviour throughout the geoengineering research literature. Nonetheless, one recurring theme among many academics is an emphasis on self-regulation. Some scholars explain that self-regulation fills the void from a lack of top-down regulation (Rayner et al. 
2013). Examples of self-regulation can be found in a number of academic articles as well as in the outcomes of the Asilomar II conference and in the creation of the Oxford Principles. The Oxford Principles are explored further here because, having been specifically referred to by IGOs, national governments, NGOs and others, they are potentially indicative of normsetting.

The first Oxford Principle - geoengineering to be regulated as a public good - explicates the importance of public funding for research. To date, most geoengineering research funding has been provided by public sources, although philanthropy has played a small role. The existence of patent applications contributed to the decision by the SPICE project leader to cancel the field trial. The actions of Russ George, who has undertaken geoengineering activities with commercial intent, are considered deviant behaviour by the academic community (Lin 2015), confirming the existence of a standard within that community.

The second principle - public participation in geoengineering decision-making - includes stakeholders whose cultural beliefs may be challenged by the concept of geoengineering. Accordingly, many academic projects have sought input from the public and from local stakeholders. For instance, a public engagement exercise was established for the SPICE project despite the project's physical risks being minor (Pidgeon et al. 2013). Even so, a number of ocean fertilisation projects have taken place without broad stakeholder consultation (Williamson et al. 2012).

The third principle - disclosure of geoengineering research and open publication of resultsaims for accountability and legitimacy, which are also emphasised in the ESG approach. However much of the academic literature is published in restricted-access journals and often is written in technical jargon. It is arguable that this third principle can be considered an accepted standard within the academic community.

The fourth principle - independent assessment of impacts - includes assessments of "environmental and socio-economic impacts of research, including mitigating the risks of lock-in to particular technologies or creation of vested interests" (Rayner et al. 2013, p. 507). This type of oversight has not been evidenced in academia or external groups. Although there have been some proposals on how to implement this concept, no such culture seems to have developed beyond the usual practice of scepticism that drives the scientific community to question new findings before these become generally accepted.

The fifth principle is governance before deployment. Although there is consensus on this principle from academic communities, the principle is problematic and again emblematic of the difficulty in navigating the contradiction between 'precaution' and 'harm minimisation'. As the authors of the Oxford Principles concede, the boundary between research and deployment of geoengineering can for some techniques be "fuzzy" (Rayner et al. 2013, p. 507), yet the principle inherently assumes that it is not.

The key standards to which the academic geoengineering community aspires are thus public participation, accountability and transparency. To some extent these are met, for example, funding is largely from public bodies and there are clear attempts at deliberation and transparency from research groups. However, there are still questions around how far deliberation and participation should reach and to what level of transparency is needed. These 
issues likely stem from the difficulty in distinguishing between deployment and research. Self-regulation is an attempt to manage this.

Finally, as noted, NGOs have had mixed responses to geoengineering, although a call for further research is increasingly common. Some NGOs have filled important agenda-setting roles by bringing geoengineering to the attention of national or international agencies, and the NGO-driven Solar Radiation Management Governance Initiative has begun a process of engagement with developing countries, but more broadly NGOs have not yet fully engaged with geoengineering and may be adopting 'wait and see' stance at this stage.

\section{The geoengineering governance landscape}

The above analysis shows that geoengineering is loosely governed in an unplanned manner by a mix of international agreements designed for other purposes. There is a regulatory standstill evidenced by the reticence of states to create laws around geoengineering at the national level. Although some countries have engaged in geoengineering discussions and provided public funding for research, this has been uncoordinated and unevenly distributed (Armeni and Redgwell 2015a; Bracmort and Lattanzio 2013). National governments seem hesitant to consider national geoengineering rulings, calling instead for increased geoengineering research and endorsing academic self-regulation through the Oxford Principles (Armeni and Redgwell 2015b, 2015a). As a result, international governance has not progressed. There is a push from many directions to increase scientific knowledge and reduce uncertainties, putting the focus on the research community.

In their bibliometric study of geoengineering research, Oldham et al. (2014) sought to highlight evolving trends in academic literature and in patenting asserting that " $[\mathrm{i}] \mathrm{n}$ the absence of an established governance framework, the practices of scientific research and intellectual property tend to shape the field and set trajectories for future development" (2014, p.2). Their analysis built on an emerging literature on research governance that positions scientists and academics as de facto governors, whose values, commitments, and actions effectively limit or prejudice the range of technology options available in the future, thereby shaping the development of that technology.

Our study looks beyond the narrow research community and suggests a different (although complementary) perspective to that of de facto governance. The term 'de facto' means 'of fact', something that is occurring (or has occurred) whether or not expressly prescribed. Certainly, scientists in the geoengineering research field are able to dictate, decide and determine a number of factors that shape what is being researched and how. This can lead to one technology or technology-type gaining momentum, while another is disregarded for reasons that may not accurately reflect the needs or wants of societies. It can also lead to certain worldviews or framings dominating the research agenda. However, a study of norms suggests that a top-down legal norm of harm minimisation already frames that research agenda and constrains it to within the ' $2 \mathrm{C} \& 0 \mathrm{Gt}$ ' target area. The ' $2 \mathrm{C} \& 0 \mathrm{Gt}$ ' target essentially establishes and defines the problem that is to be solved. Thus, in summary, de facto governance expresses the ability of the research community to steer the research agenda of emerging technologies by establishing programs, networks and institutions that set the evolution of those technologies within the ' $2 \mathrm{C} \& 0 \mathrm{Gt}$ ' target. 
Rather than de facto governance, here, we find that geoengineering is in a state of 'governance-by-default', with the term 'by-default' meaning 'for lack of opposition'. That is, academics are acting to the full extent of their capacities, and potentially beyond, for lack of any barriers, within and beyond the research arena. The characteristics that define this 'governance-by-default' are an absence of purposive regulation, an existing driver (here, the '2C\&0Gt' target as established by a norm of harm minimisation), a propensity for regulators to postpone decision-making (here, in anticipation of improved scientific certainty to resolve the tension between precaution and harm minimisation), engagement dominated by one actorgroup (here, academia), and ultimately a blurring of the lines between the different roles of societal players (here, related to the difficulty in separating research from deployment). Scientists have taken on the responsibility of self-regulation and begun to stray into a broader role of governance by advocating terms of deployment, not just research.

De facto governance of the research agenda is a part of the concept of geoengineering governance-by-default, but it is only one element. Governance-by-default is a broader concept. It encompasses also the values associated with geoengineering, and its treatment by the non-academic community. Through such initiatives as the Oxford Principles and other attempts at self-regulation, the research community seeks to anticipate and to respond to concerns of societies thus shaping more than just the research agenda. Against the backdrop of passive governments and NGOs, the actions of the research community are amplified. Returning to the distinction between actors and agents, it can be argued that the research community, by being more responsive to, and participatory in, issues of geoengineering than public institutions, have been conferred legitimate authority. These actors thus become lead agents in geoengineering governance until other authorities become engaged.

Governance-by-default is likely a transitory form of governance, existing only until discernible and effective forms of deliberation emerge or a crisis arises. In the case of geoengineering, it may evolve as a learning-by-doing governance related directly to the management of individual technologies. For example, a series of ocean fertilisation trials triggered debate amongst NGOs, IGOs and some governments and resulted in the development of restrictive governance measures within the CBD and LC/LP. These could eventually form the basis of broader geoengineering governance. As cloud brightening, stratospheric aerosols, or another technology reach sufficient scientific maturity, interests in or against these technologies are likely to develop. The boundaries between these interests of different actors may define the next formative stages of geoengineering governance.

This type of governance has emerged because governments have adopted a 'wait and see' approach as a reaction to the contradiction of enabling research while disabling deployment when there are only soft barriers between the two. A 'wait and see' approach allows governments and regulators to ensure that governance matches the realities of the technologies. Yet, this assumes that further research will reduce uncertainties sufficiently to allow control of environmental outcomes and to provide a basis for regulation. This ignores that, under a governance-by-default situation, researchers already influence prospective regulation. The definition of ESG establishes that governance of environmental transitions occur in a purposeful manner (steered) and in consideration of the needs of future generations (sustainable development). It can be argued that geoengineering governance-by-default does have an element of steering - the direction is set by the level and type of engagement from 
various actor groups on a reactive basis. It is being steered by the ' $2 \mathrm{C} \& 0 \mathrm{Gt}$ ' target, by scientists' interpretation of that target and by the isolated actions of NGOs, IGOs and individuals in response to the science. However, it is difficult to argue that this steering has an end-goal or clear purpose within the context of sustainable development. Although the '2C\&0Gt' target and legal norms of harm minimisation align with sustainability values, governance-by-default is reactive; it offers no coordinated proactive management of emerging issues. As a result, it could ignore potential threats and opportunities that may emerge for future generations, unlike anticipatory governance, which values reflexivity and foresight (Guston 2014).

\section{Conclusion}

Geoengineering could contribute to the climate change problem in either a remedial or antagonistic manner, depending on how it is managed. A proactive approach to the future of geoengineering governance is needed to avoid the negative outcomes and promote optimal outcomes for all. Having examined how geoengineering is governed, this paper concurs with Larson (2016), finding that international agreements mostly provide only unplanned and piecemeal governance over geoengineering at the global scale. Its analysis also establishes that this lack of direct and intentional governance extends to the national level, where it seems that governments are reticent to provide clear guidance on geoengineering. In the absence of an explicit international effort to govern geoengineering towards any agreed outcome, one cannot refer to a fully articulated geoengineering regime at this stage. Instead, we find a form of governance-by-default that is not guided by an overarching strategy.

This type of governance has emerged because, while one group of actors (academic researchers) is responding actively, governments plus other actors have adopted a 'watching brief' on the issue, due to an inability to reconcile two conflicting legal norms: that of precaution, and that of harm minimisation. Governance-by-default of geoengineering will persist until the 'watching brief' of governments (or other actor groups such as NGOs) comes to an end and a regime transpires.

Nonetheless, it could have permanent effects on enduring governance. It defines the formation of interest groups, especially those opposed to individual geoengineering technologies, and sets the issues of concern on an ad hoc basis. It also enables the de facto governance role of academics. By submitting such high-stakes technologies to scientific inertia, governments risk losing the ability to intervene in the fate of these technologies. In this study, we have not explored the ESG concepts of scale, knowledge and power, but these elements are clearly relevant in the context of governance-by-default and warrant further analysis. Similarly, the prevalence of certain actor groups as key agents of geoengineering governance raises issues of accountability and legitimacy that merit additional consideration.

Some scholars have argued that adaptive governance is required to respond to changing knowledge and societal norms relating to geoengineering and to help shape them (Payne et al. 2015). Instead, our study suggests the need for anticipatory governance, which also prioritises public participation, deliberation and adaptive management, but emphasises the need for foresight as an overarching framework. To transition governance-by-default to a more enduring solution within the context of sustainable development, forward-looking engagement that elucidates possible future scenarios of geoengineering deployment and 
governance is needed from all nations, including those that have not engaged in the debate thus far. Informed, interdisciplinary and deliberative research could help structure purposive governance of geoengineering, and ensure that knowledge production embraces a broad range of views and interests. 


\section{References}

Abbott, K. W., \& Snidal, D. (2000). Hard and Soft Law in International Governance. International Organization, 54(03), 421-456. doi:10.1162/002081800551280

Armeni, C., \& Redgwell, C. (2015a). Geoengineering Under National Law: A Case Study Of The United Kingdom (No. 23). Climate Geoengineering Governance.

Armeni, C., \& Redgwell, C. (2015b). Geoengineering Under National Law: A Case Study of Germany (No. 24). Climate Geoengineering Governance.

Asilomar Scientific Organizing Committee. (2010). The Asilomar Conference Recommendations on Principles for Research into Climate Engineering Techniques. Washington DC: Climate Institute.

Belter, C. W., \& Seidel, D. J. (2013). A bibliometric analysis of climate engineering research. Wiley Interdisciplinary Reviews: Climate Change, 4(5), 417-427. doi:10.1002/wcc.229

Biermann, F., Betsill, M. M., Gupta, J., Kanie, N., Lebel, L., Liverman, D., et al. (2010). Earth system governance: a research framework. International Environmental Agreements: Politics, Law and Economics, 10(4), 277-298. doi:10.1007/s10784-010-9137-3

Biermann, F., Pattberg, P., van Asselt, H., \& Zelli, F. (2009). The Fragmentation of Global Governance Architectures: A Framework for Analysis. Global Environmental Politics, 9(4), 14-40. doi:10.1162/glep.2009.9.4.14

Bodansky, D. (2011). Governing climate engineering: scenarios for analysis. Harvard Project on Climate Agreements Discussion Paper.

Bodle, R., Oberthür, S., Donat, L., Homann, G., Sina, S., \& Tedsen, E. (2014). Options and Proposals for the International Governance of Geoengineering. Berlin: Ecologic Institute.

Bracmort, K. L., Richard K., \& Lattanzio, R. K. (2013). Geoengineering: governance and technology policy. Congressional Research Service Library of Congress. 
Brent, K., McGee, J., \& Maguire, A. (2015). Does the 'No-Harm' Rule Have a Role in Preventing Transboundary Harm and Harm to the Global Atmospheric Commons from Geoengineering? Climate Law, 5(1), 35-63. doi:10.1163/18786561-00501007

Brent, K., McGee, J., \& McDonald, J. (2016). The Governance of Geoengineering An Emerging Challenge for International and Domestic Legal Systems. Journal of Law, Information \& Science, 24. http://www.jlisjournal.org/abstracts/BrentMcGeeMcDonald.24.1.html

Cairns, R. (2014). Climates of suspicion: 'chemtrail' conspiracy narratives and the international politics of geoengineering. The Geographical Journal, n/a-n/a. doi:10.1111/geoj.12116 CBD COP. (2010). Decision adopted by the Conference of the Parties to the Convention on Biological Diversity at its tenth meeting, UNEP/CBD/COP/DEC/X/33 29 October 2010.

CBD COP. (2016). Decision adopted by the Conference of the Parties to the Convention on Biological Diversity at its thirteenth meeting, UNEP/CBD/COP/DEC/XIII/14 8 December 2016.

CBD Secretariat. (2012). Geoengineering in relation to the convention on biological diversity: technical and regulatory matters (No. 66) (p. 152 pp.). Montreal.

Chinkin, C. M. (1989). The Challenge of Soft Law: Development and Change in International Law. International \& Comparative Law Quarterly, 38(04), 850-866. doi:10.1093/iclqaj/38.4.850 Convention on Biological Diversity. Decision X/33 (2010). Convention on International Liability for Damage Caused by Space Objects, opened for signature 29 March 1972, 24 UST 2389 (entered into force 1 September 1972) ('Liability Convention').

Cressey, D. (2012). Geoengineering experiment cancelled amid patent row. Nature, 10, 1038. doi:10.1038/nature.2012.10645

Crutzen, P. J. (2006). Albedo enhancement by stratospheric sulfur injections: A contribution to resolve a policy dilemma? Climatic Change, 77(3), 211-220. doi:10.1007/s10584-006-9101-y

Dellas, E., Pattberg, P., \& Betsill, M. (2011). Agency in earth system governance: refining a research agenda. International Environmental Agreements: Politics, Law and Economics, 11(1), 85-98. doi:10.1007/s10784-011-9147-9 
Department of Energy \& Climate Change (DECC). (2010). Government Response to the House of Commons Science and Technology Committee 5th Report of Session 2009-10: The Regulation of Geoengineering. United Kingdom: The Stationery Office Limited.

Elliott, K. (2010). Geoengineering and the Precautionary Principle. International Journal of Applied Philosophy, 24(2), 237-253. doi:10.5840/ijap201024221

Finnemore, M., \& Sikkink, K. (1998). International Norm Dynamics and Political Change. International Organization, 52(4), 887-917. doi:10.1162/002081898550789

Geoengineering: Parts I, II, and III--Hearing before the Committee on Science and Technology House of Representatives One Hundred Eleventh Congress First Session and Second Session (2010). Greenpeace International. (2007). Planktos, Inc., Large-scale Ocean Iron Addition Projects:

Submission to Scientific Group of the London Convention 30th meeting and London Protocol 1st Meeting, 18-22 June 2007, LC/SG 30/12/1.

Guston, D. H. (2014). Understanding 'anticipatory governance.' Social Studies of Science, 44(2), 218242. doi:10.1177/0306312713508669

Humphreys, D. (2011). Smoke and Mirrors: Some Reflections on the Science and Politics of Geoengineering. The Journal of Environment \& Development, 20(2), 99-120. doi:10.1177/1070496511405302

iagp.ac.uk. (2015). Who we are | IAGP. http://iagp.ac.uk/who-we-are. Accessed 31 January 2016 IPCC. (2013). Climate Change 2013: The Physical Science Basis. Contribution of Working Group I to the Fifth Assessment Report of the Intergovernmental Panel on Climate Change. (T. Stocker, D. Qin, G. Plattner, M. Tignor, S. Allen, J. Boschung, et al., Eds.). Cambridge, United Kingdom and New York, NY, USA: Cambridge University Press.

IUCN. (2007). Planktos, Inc., Large-scale Ocean Iron Addition Projects: Submission to Scientific Group of the London Convention 30th meeting and London Protocol 1st Meeting, 18-22 June 2007, LC/SG 30/12. 
Keith, D. W. (2000). Geoengineering the climate: History and Prospect. Annual Review of Energy and the Environment, 25(1), 245-284. doi:10.1146/annurev.energy.25.1.245

Keith, D. W. (2013). A case for climate engineering. Cambridge, Mass: The MIT Press.

Keith, D. W., Duren, R., \& MacMartin, D. G. (2014). Field experiments on solar geoengineering: report of a workshop exploring a representative research portfolio. Phil. Trans. R. Soc. A, 372(2031), 20140175. doi:10.1098/rsta.2014.0175

Keith, D. W., \& MacMartin, D. G. (2015). A temporary, moderate and responsive scenario for solar geoengineering. Nature Climate Change, 5(3), 201-206. doi:10.1038/nclimate2493

Keith, D. W., Parson, E., \& Morgan, M. G. (2010). Research on global sun block needed now. Nature, 463(7280), 426-427. doi:10.1038/463426a

Keohane, R. O., \& Victor, D. G. (2011). The Regime Complex for Climate Change. Perspectives on Politics, 9(01), 7-23. doi:10.1017/S1537592710004068

Krasner, S. D. (Ed.). (1983). International regimes. Ithaca: Cornell University Press.

Kravitz, B., MacMartin, D. G., Robock, A., Rasch, P. J., Ricke, K. L., Cole, J. N. S., et al. (2014). A multimodel assessment of regional climate disparities caused by solar geoengineering. Environmental Research Letters, 9(7), 074013. doi:10.1088/1748-9326/9/7/074013

Larson, E. J. (2016). The Red Dawn of Geoengineering: First Step toward an Effective Governance for Stratospheric Injections. Duke Law \& Technology Review, 14, 157-191.

LC/LP. (2008). Resolution LC-LP.1(2008) on the regulation of ocean fertilization.

LC/LP. (2013). Annex 4 Resolution LP.4(8) on the amendment to the London Protocol to regulate the placement of matter for ocean fertilization and other marine geoengineering activities.

Le Quéré, C., Moriarty, R., Andrew, R. M., Canadell, J. G., Sitch, S., Korsbakken, J. I., et al. (2015). Global Carbon Budget 2015. Earth System Science Data, 7(2), 349-396. doi:10.5194/essd-7$349-2015$ 
Lenton, T. M. (2014). The Global Potential for Carbon Dioxide Removal. In R. M. Harrison, R. E. Hester, \& Royal Society of Chemistry (Great Britain) (Eds.), Geoengineering of the climate system (pp. 52-79). Cambridge: Royal Society of Chemistry.

Lin, A. C. (2015). The Missing Pieces of Geoengineering Research Governance. Minnesota Law Review, 100, 2509-2576.

Mercer, A. M., Keith, D. W., \& Sharp, J. D. (2011). Public understanding of solar radiation management. Environmental Research Letters, 6(4), 044006. doi:10.1088/1748$9326 / 6 / 4 / 044006$

National Research Council. (2015a). Climate Intervention: Carbon Dioxide Removal and Reliable Sequestration. Washington, DC: The National Academies Press. http://www.nap.edu/catalog/18805/climate-intervention-carbon-dioxide-removal-andreliable-sequestration

National Research Council. (2015b). Climate Intervention: Reflecting Sunlight to Cool Earth. Washington, DC: The National Academies Press. http://www.nap.edu/catalog/18988/climate-intervention-reflecting-sunlight-to-cool-earth

NERC. (2016, September). Greenhouse Gas Removal from the Atmosphere Announcement of Opportunity. Natural Environment Research Council (NERC).

Nicholson, S., \& Thompson, M. (2015). Strange bedfellows: climate engineering politics in the United States (Opinion Article).

Oldham, P., Szerszynski, B., Stilgoe, J., Brown, C., Eacott, B., \& Yuille, A. (2014). Mapping the landscape of climate engineering. Philosophical Transactions of the Royal Society A, 372. doi:10.1098/rsta.2014.0065

Pattberg, P., \& Stripple, J. (2008). Beyond the public and private divide: remapping transnational climate governance in the 21st century. International Environmental Agreements: Politics, Law and Economics, 8(4), 367-388. doi:10.1007/s10784-008-9085-3 
Pattberg, P., Widerberg, O., Isailovic, M., \& Dias Guerra, F. (2014). Mapping and Measuring Fragmentation in Global Governance Architectures: A Framework for Analysis. Available at SSRN 2484513. http://papers.ssrn.com/sol3/papers.cfm?abstract_id=2484513. Accessed 17 June 2016

Payne, C. R., Shwom, R., \& Heaton, S. (2015). Public Participation and Norm Formation for Risky Technology: Adaptive Governance of Solar-Radiation Management. Climate Law, 5(2-4), 210-251. doi:10.1163/18786561-00504005

Pidgeon, N., Parkhill, K., Corner, A., \& Vaughan, N. (2013). Deliberating stratospheric aerosols for climate geoengineering and the SPICE project. Nature Clim. Change, 3(5), 451-457. doi:10.1038/nclimate1807

Rayner, S., Heyward, C., Kruger, T., Pidgeon, N., Redgwell, C., \& Savulescu, J. (2013). The Oxford Principles. Climatic Change, 121(3), 499-512. doi:10.1007/s10584-012-0675-2

Reynolds, J. L. (2014). A critical examination of the climate engineering moral hazard and risk compensation concern. The Anthropocene Review. doi:10.1177/2053019614554304

Rickels, W., Klepper, G., Dovern, J., Betz, G., Brachatzek, N., Cacean, S., et al. (2011). Large-scale intentional interventions into the climate system (Scoping Report). Kiel: Kiel Earth Institute.

Robock, A. (2008). 20 reasons why geoengineering may be a bad idea. Bulletin of the Atomic Scientists.

Robock, A., Bunzl, M., Kravitz, B., \& Stenchikov, G. L. (2010). A Test for Geoengineering? Science, 327(5965), 530-531. doi:10.1126/science.1186237

Royal Society. (2009). Geoengineering the climate: science, governance and uncertainty (Policy document). London, UK: Royal Society.

Schneider, S. H. (1996). Geoengineering: Could - or should - we do it? Climatic Change, 33(3), 291302. doi:10.1007/BF00142577

Scott, K. N. (2012). International Law in the Anthropocene: Responding to the Geoengineering Challenge. Michigan Journal of International Law, 34, 309-358. 
The Paris Agreement to the United Nations Framework Convention on Climate Change, opened for signature 22 April 2016 ('Paris Agreement').

Tollefson, J. (2010). Geoengineering faces ban. Nature News, 468(7320), 13-14. doi:10.1038/468013a

Treaty on Principles Governing the Activities of States in the Exploration and Use of Outer Space, including the Moon and Other Celestial Bodies, opened for signature 27 January 1967, 610 UNTS 205 (entered into force 10 October 1967) ('Outer Space Treaty').

UN General Assembly. (2015, October 21). Resolution adopted by the General Assembly on 25 September 2015: Transforming our world: the 2030 Agenda for Sustainable Development. United Nations Framework Convention on Climate Change, opened for signature 4 June 1992, 1771 UNTS 107 (entered into force 21 March 1994) ('UNFCCC').

United States (US). (2007). Planktos, Inc., Large-scale Ocean Iron Addition Projects: Submission to Scientific Group of the London Convention 30th meeting and London Protocol 1st Meeting, 18-22 June 2007, LC/SG 30/INF.28.

Vaughan, N. E., \& Lenton, T. M. (2011). A review of climate geoengineering proposals. Climatic Change, 109(3-4), 745-790. doi:10.1007/s10584-011-0027-7

Virgoe, J. (2009). International governance of a possible geoengineering intervention to combat climate change. Climatic Change, 95(1-2), 103-119. doi:10.1007/s10584-008-9523-9 Wallace, D., Law, C., Boyd, P., Collos, Y., Croot, P., Denman, K., et al. (2010). Ocean fertilization: A scientific summary for policy makers. http://eprints.unikiel.de/11908/1/2010_OceanFertilization_SOLAS.pdf. Accessed 21 November 2015

Walsh, B. (2010, November 2). Climate: Why It's a Mistake to Ban Research on Geoengineering. Time. http://science.time.com/2010/11/02/climate-why-its-a-mistake-to-ban-research-ongeoengineering/. Accessed 2 July 2017 
Watson, M. (2012, May 16). Testbed news. the reluctant geoengineer.

http://thereluctantgeoengineer.blogspot.com.au/2012/05/testbed-news.html. Accessed 4 October 2014

WCED. (1987). Our common future: Report of the World Commission on Environment and Development. World Commission on Environment and Development.

Williamson, P., Wallace, D. W. R., Law, C. S., Boyd, P. W., Collos, Y., Croot, P., et al. (2012). Ocean fertilization for geoengineering: A review of effectiveness, environmental impacts and emerging governance. Process Safety and Environmental Protection, 90(6), 475-488. doi:10.1016/j.psep.2012.10.007 
Table for "Geoengineering governance-by-default: an Earth System Governance perspective" Table 1: International legal instruments relevant to geoengineering

\begin{tabular}{|c|c|c|c|}
\hline $\begin{array}{l}\text { Instrument } \\
\text { (Membership) }\end{array}$ & $\begin{array}{l}\text { Treaty's main } \\
\text { objective }\end{array}$ & Articles, protocols or amendments of potential relevance to geoengineering & $\begin{array}{l}\text { Technologies of } \\
\text { potential relevance }\end{array}$ \\
\hline $\begin{array}{l}\text { UN Convention on the Law of } \\
\text { the Sea (UNCLOS) } \\
\text { (168 parties - does not include } \\
\text { the US) }\end{array}$ & $\begin{array}{l}\text { Establishes the legal } \\
\text { framework for } \\
\text { allocating, protecting } \\
\text { and preserving the } \\
\text { marine environment. }\end{array}$ & $\begin{array}{l}\text { Countries with coastal areas have jurisdiction over their maritime zone and the airspace } \\
\text { above it. To conduct an activity in another country's internal or territorial waters requires } \\
\text { consent (Redgwell 2011; Rickels et al. 2011). Environmental impact assessment is required } \\
\text { for potentially risky projects. }\end{array}$ & $\begin{array}{l}\text { Ocean fertilisation; } \\
\text { ocean liming; CCS; } \\
\text { up- or down-welling; } \\
\text { cloud brightening } \\
\text { from ships }\end{array}$ \\
\hline \multirow{3}{*}{$\begin{array}{l}\text { Convention on the Prevention } \\
\text { of Marine Pollution by } \\
\text { Dumping of Wastes and Other } \\
\text { Matter (London Convention) } \\
\text { ( } 87 \text { parties - includes the EU, } \\
\text { the US, Canada, Russia and } \\
\text { China) }\end{array}$} & \multirow{3}{*}{$\begin{array}{l}\text { Regulates activities } \\
\text { that may constitute } \\
\text { ocean pollution }\end{array}$} & $\begin{array}{l}\text { The London Protocol to the London Convention (LC/LP), which has } 47 \text { parties (and does not } \\
\text { include the US or Russia), has passed resolutions relating to ocean fertilisation. A } 2008 \\
\text { resolution was passed stating that "ocean fertilization activities other than legitimate } \\
\text { scientific research ... should be considered as contrary to the aims of the Convention and } \\
\text { Protocol and not currently qualify for any exemption from the definition of dumping" (LC/LP } \\
\text { 2008) }\end{array}$ & \multirow{3}{*}{ Ocean fertilisation } \\
\hline & & $\begin{array}{l}\text { A } 2010 \text { resolution provides guidance to Parties on assessing ocean fertilization research } \\
\text { proposals and for completing an environmental assessment with risk management and } \\
\text { monitoring (LC/LP 2010). }\end{array}$ & \\
\hline & & $\begin{array}{l}\text { An LC/LP amendment regulates marine geoengineering activities and adds two new annexes: } \\
\text { a list of regulated marine geoengineering activities (currently only ocean fertilisation is } \\
\text { listed), and an assessment framework to define legitimate scientific research (LC/LP 2013). } \\
\text { (the amendment has been adopted but is not in force) }\end{array}$ & \\
\hline $\begin{array}{l}\text { International Convention for } \\
\text { the Prevention of Pollution } \\
\text { from Ships and Protocol } \\
\text { (MARPOL 73/78) } \\
\text { (155 parties) }\end{array}$ & $\begin{array}{l}\text { Aim to eliminate } \\
\text { marine pollution and } \\
\text { accidental spillage of } \\
\text { oil and other harmful } \\
\text { substances resulting } \\
\text { from ships. }\end{array}$ & $\begin{array}{l}\text { Within certain specially designated protected areas, the Convention and its Protocol limit } \\
\text { discharge into the sea of hazardous substances (Bodle et al. 2014). }\end{array}$ & $\begin{array}{l}\text { Ocean fertilization; } \\
\text { ocean liming }\end{array}$ \\
\hline \multirow{2}{*}{$\begin{array}{l}\text { Convention on Long Range } \\
\text { Transboundary Air Pollution } \\
\text { (CLRTAP) } \\
\text { (51 parties -does not include } \\
\text { China) }\end{array}$} & \multirow{2}{*}{$\begin{array}{l}\text { Limits transboundary } \\
\text { air pollution. }\end{array}$} & The Convention itself limits emissions of substances that "result in deleterious effects". & $\begin{array}{l}\text { Stratospheric aerosol } \\
\text { injection; cloud } \\
\text { brightening }\end{array}$ \\
\hline & & $\begin{array}{l}\text { The protocols list certain substances. Three protocols establish quantified limits for sulfur } \\
\text { emissions (but these protocols have fewer than } 30 \text { signatories) (Rickels et al. 2011). }\end{array}$ & $\begin{array}{l}\text { Stratospheric aerosol } \\
\text { injection }\end{array}$ \\
\hline
\end{tabular}




\begin{tabular}{|c|c|c|c|}
\hline $\begin{array}{l}\text { Instrument } \\
\text { (Membership) }\end{array}$ & $\begin{array}{l}\text { Treaty's main } \\
\text { objective }\end{array}$ & Articles, protocols or amendments of potential relevance to geoengineering & $\begin{array}{l}\text { Technologies of } \\
\text { potential relevance }\end{array}$ \\
\hline $\begin{array}{l}\text { Vienna Convention on the } \\
\text { Protection of the Ozone Layer } \\
\text { (196 parties - includes the US) }\end{array}$ & $\begin{array}{l}\text { Establishes a legal } \\
\text { framework for } \\
\text { protecting the ozone } \\
\text { layer. }\end{array}$ & $\begin{array}{l}\text { The Convention sets out general obligation for Parties to "protect human health and the } \\
\text { environment against adverse effects [...] from human activities which modify or are likely to } \\
\text { modify the ozone layer" (Vienna Convention art II) }\end{array}$ & $\begin{array}{l}\text { Stratospheric aerosol } \\
\text { injection; cloud } \\
\text { brightening }\end{array}$ \\
\hline \multirow[t]{2}{*}{$\begin{array}{l}\text { United Nations Framework } \\
\text { Convention on Climate } \\
\text { Change (UNFCCC) } \\
\text { (197 parties - includes the US) }\end{array}$} & \multirow[t]{2}{*}{$\begin{array}{l}\text { Establishes a legal } \\
\text { framework for manage } \\
\text { a global climate } \\
\text { change response. }\end{array}$} & $\begin{array}{l}\text { The treaty's ultimate objective is stabilization of atmospheric greenhouse gas concentrations } \\
\text { at a level that would prevent dangerous anthropogenic interference with the climate system. } \\
\text { Article 4(d) urges all Parties to "promote and cooperate in the conservation and } \\
\text { enhancement, as appropriate, of sinks and reservoirs [...] including biomass, forests and } \\
\text { oceans as well as other terrestrial, coastal and marine ecosystems" (UNFCCC art 4(d)). } \\
\text { Also, the Paris Agreement to the UNFCCC establishes an aim "to achieve a balance between } \\
\text { anthropogenic emissions by sources and removals by sinks of greenhouse" (Paris Agreement } \\
\text { art 4). }\end{array}$ & $\mathrm{CDR}$ \\
\hline & & $\begin{array}{l}\text { The Paris Agreement defines a goal of staying well below two degrees, and aiming for } 1.5 \\
\text { degrees. However, it emphasises the need to ensure that action is taken in a manner that "does } \\
\text { not threaten food production" for example (Paris Agreement art 2), and that it is achieved on } \\
\text { "the basis of equity, and in the context of sustainable development" (Paris Agreement art } 4 \text { ). }\end{array}$ & SRM \\
\hline $\begin{array}{l}\text { Convention on Biological } \\
\text { Diversity (CBD) } \\
\text { (196 parties - does not include } \\
\text { the US) }\end{array}$ & $\begin{array}{l}\text { Aims for the } \\
\text { conservation and } \\
\text { sustainable use of } \\
\text { biological diversity } \\
\text { with fair and equitable } \\
\text { sharing of the benefits } \\
\text { arising out of such } \\
\text { resource use. }\end{array}$ & $\begin{array}{l}\text { The Convention itself cautions against activities that threaten biodiversity and promotes } \\
\text { activities that conserve biodiversity. The Conference of the Parties (COP) has adopted three } \\
\text { decisions that relate to geoengineering. In 2008, the COP cautioned precautionary behaviour } \\
\text { with regard to ocean fertilisation (CBD COP 2008). In 2010, the COP invited Parties to } \\
\text { ensure that no geoengineering activities with potential biodiversity impacts take place "in the } \\
\text { absence of science based, global, transparent and effective control and regulatory } \\
\text { mechanisms", but "with the exception of small scale scientific research studies" (CBD COP } \\
\text { 2010, para. } 8 \text { (w)). In 2012, the COP invited Parties to address climate engineering research } \\
\text { gaps (CBD COP 2012). The scientific advisory body of the CBD COP (the Subsidiary Body } \\
\text { on Scientific, Technical and Technological Advice (SBSTTA)) was instructed to undertake a } \\
\text { three studies relating to geoengineering. The SBSTTA produced three reviews: one on the } \\
\text { science and impacts, one on the legal framework, and one on the view of indigenous and } \\
\text { local communities (CBD SBSTTA 2012a, 2012b, 2012c). The latter involved meetings and } \\
\text { electronic discussions with relevant stakeholders, and was conducted with assistance from } \\
\text { UNESCO, the UN Permanent Forum on Indigenous Issues and the Office of the High } \\
\text { Commissioner on Human Rights. }\end{array}$ & $\begin{array}{l}\text { All geoengineering } \\
\text { proposals }\end{array}$ \\
\hline
\end{tabular}




\begin{tabular}{|c|c|c|c|}
\hline $\begin{array}{l}\text { Instrument } \\
\text { (Membership) }\end{array}$ & $\begin{array}{l}\text { Treaty's main } \\
\text { objective }\end{array}$ & Articles, protocols or amendments of potential relevance to geoengineering & $\begin{array}{l}\text { Technologies of } \\
\text { potential relevance }\end{array}$ \\
\hline $\begin{array}{l}\text { United Nations Convention to } \\
\text { Combat Desertification in } \\
\text { Those Countries Experiencing } \\
\text { Serious Drought and/or } \\
\text { Desertification, Particularly in } \\
\text { Africa (UNCCD) } \\
\text { (196 parties) }\end{array}$ & $\begin{array}{l}\text { Aims to combat } \\
\text { desertification and } \\
\text { mitigate the effects of } \\
\text { drought. }\end{array}$ & $\begin{array}{l}\text { The Convention encourages national programs and international cooperation targeting } \\
\text { desertification. It is relevant to geoengineering to the extent that these may affect the } \\
\text { hydrological cycle. }\end{array}$ & $\begin{array}{l}\text { All geoengineering } \\
\text { proposals }\end{array}$ \\
\hline $\begin{array}{l}\text { Outer space treaties (OSTs) } \\
\text { (104 parties - includes US, } \\
\text { Russia, EU, Australia and } \\
\text { China) }\end{array}$ & $\begin{array}{l}\text { Establishes the legal } \\
\text { framework for } \\
\text { international space } \\
\text { law. }\end{array}$ & $\begin{array}{l}\text { Requires that space exploration "be carried out for the benefit and in the interests of all } \\
\text { countries [...] and shall be the province of all mankind" (Outer Space Treaty art I) Any use } \\
\text { of space must be for peaceful purposes (Outer Space Treaty art IV) and a launching State is } \\
\text { liable for damage caused by its space object (Space Liability Convention art II) }\end{array}$ & Space-based SRM \\
\hline $\begin{array}{l}\text { Convention on the Prohibition } \\
\text { of Military or Any Other } \\
\text { Hostile Use of Environmental } \\
\text { Modification Techniques } \\
\text { (ENMOD) } \\
\text { ( } 77 \text { parties - includes, the EU, } \\
\text { the US, Russia and China) }\end{array}$ & $\begin{array}{l}\text { Prohibits military or } \\
\text { hostile usage of } \\
\text { environmental } \\
\text { modification. }\end{array}$ & $\begin{array}{l}\text { Environmental modification is defined as "any technique for changing - through the } \\
\text { deliberate manipulation of natural processes - the dynamics, composition or structure of the } \\
\text { Earth, including its biota, lithosphere, hydrosphere and atmosphere, or of outer space" } \\
\text { (ENMOD Convention art II). The Convention promotes research into, and collaboration on } \\
\text { such activities if they are for peaceful purposes (Winter 2011). Prohibition applies only if } \\
\text { another contracting Party endures destruction, damage or injury that is widespread, long- } \\
\text { lasting or severe (Lin 2009). }\end{array}$ & $\begin{array}{l}\text { All geoengineering } \\
\text { proposals }\end{array}$ \\
\hline $\begin{array}{l}\text { Antarctic Treaty System } \\
\text { (ATS) } \\
(\mathbf{5 3} \text { parties, only } 29 \text { with } \\
\text { voting status - includes the } \\
\text { US, Russia, Australia and } \\
\text { some EU countries) }\end{array}$ & $\begin{array}{l}\text { Regulates the use of } \\
\text { Antarctica. }\end{array}$ & $\begin{array}{l}\text { The Convention's Protocol on Environmental Protection to the Antarctic Treaty requires that } \\
\text { activities be planned and conducted to avoid "adverse effects on climate or weather patterns" } \\
\text { (PEPAT art 3.2(b)(i)). Scientific research into geoengineering, such as ocean fertilisation, } \\
\text { would be permitted with a requirement for "due consideration [...] to avoid detrimental } \\
\text { effects on dependent and associated ecosystems, outside the Antarctic Treaty area" (Lin } \\
\text { 2009), "significant adverse effects on air or water quality"; or "significant changes in the } \\
\text { atmospheric, terrestrial (including aquatic), glacial or marine environments" (Scott 2012) }\end{array}$ & $\begin{array}{l}\text { All geoengineering } \\
\text { proposals }\end{array}$ \\
\hline
\end{tabular}




\section{References}

Bodle, R., Oberthür, S., Donat, L., Homann, G., Sina, S., \& Tedsen, E. (2014). Options and Proposals for the International Governance of Geoengineering. Berlin: Ecologic Institute.

CBD COP. (2008). Decision adopted by the Conference of the Parties to the Convention on Biological Diversity at its ninth meeting, UNEP/CBD/COP/DEC/IX/16 9 October 2008.

CBD COP. (2010). Decision adopted by the Conference of the Parties to the Convention on Biological Diversity at its tenth meeting, UNEP/CBD/COP/DEC/X/33 29 October 2010.

CBD COP. (2012). Decision adopted by the Conference of the Parties to the Convention on Biological Diversity at its eleventh meeting, UNEP/CBD/COP/DEC/XI/20 5 December 2012.

CBD SBSTTA. (2012a, April 2). Regulatory framework for climate-related geoengineering relevant to the Convention on Biological Diversity UNEP/CBD/SBSTTA/16/INF/29.

CBD SBSTTA. (2012b, April 5). Impacts of climate-related geoengineering on biological diversity UNEP/CBD/SBSTTA/16/INF/28.

CBD SBSTTA. (2012c, April 17). Impacts of climate-related geoengineering on biodiversity: views and experiences of indigenous and local communities and stakeholders UNEP/CBD/SBSTTA/16/INF/30.

Convention on International Liability for Damage Caused by Space Objects, opened for signature 29 March 1972, 24 UST 2389 (entered into force 1 September 1972) ('Liability Convention'). Convention on the Prohibition of Military or Other Hostile Use of Environmental Modification Techniques, opened for signature 10 December 1976, 1108 UNTS 151 (entered into force 5 October 1978) ('ENMOD Convention').

Humphreys, D. (2011). Smoke and Mirrors: Some Reflections on the Science and Politics of Geoengineering. The Journal of Environment \& Development, 20(2), 99-120. doi:10.1177/1070496511405302

LC/LP. (2008). Resolution LC-LP.1(2008) on the regulation of ocean fertilization. 
LC/LP. (2010). Resolution LC-LP.2(2010) on the assessment framework for scientific research involving ocean fertilization.

LC/LP. (2013). Annex 4 Resolution LP.4(8) on the amendment to the London Protocol to regulate the placement of matter for ocean fertilization and other marine geoengineering activities.

Lin, A. C. (2009). Geoengineering Governance. Issues in Legal Scholarship, 8(1). doi:10.2202/15398323.1112

Protocol on Environmental Protection to the Antarctic Treaty, opened for signature 4 October 1991, 30 ILM 1455 (entered into force 14 January 1998) ('PEPAT').

Redgwell, C. (2011). Geoengineering the Climate: Technological Solutions to Mitigation - Failure or Continuing Carbon Addiction Thematic Focus: Climate Change Governance - The International Regime Complex. Carbon \& Climate Law Review, 2011, 178-189.

Rickels, W., Klepper, G., Dovern, J., Betz, G., Brachatzek, N., Cacean, S., et al. (2011). Large-scale intentional interventions into the climate system (Scoping Report). Kiel: Kiel Earth Institute.

Scott, K. N. (2012). International Law in the Anthropocene: Responding to the Geoengineering Challenge. Michigan Journal of International Law, 34, 309-358.

The Paris Agreement to the United Nations Framework Convention on Climate Change, opened for signature 22 April 2016 ('Paris Agreement').

The Vienna Convention for the Protection of the Ozone Layer, opened for signature 22 March 1985, 1513 UNTS 293 (entered into force 22 September 1985) ('Vienna Convention').

Treaty on Principles Governing the Activities of States in the Exploration and Use of Outer Space, including the Moon and Other Celestial Bodies, opened for signature 27 January 1967, 610 UNTS 205 (entered into force 10 October 1967) ('Outer Space Treaty').

United Nations Framework Convention on Climate Change, opened for signature 4 June 1992, 1771 UNTS 107 (entered into force 21 March 1994) ('UNFCCC'). 
Winter, G. (2011). Climate Engineering and International Law: Last Resort or the End of Humanity? Review of European Community \& International Environmental Law, 20(3), 277-289. doi:10.1111/j.1467-9388.2012.00730.x

Fig. 1

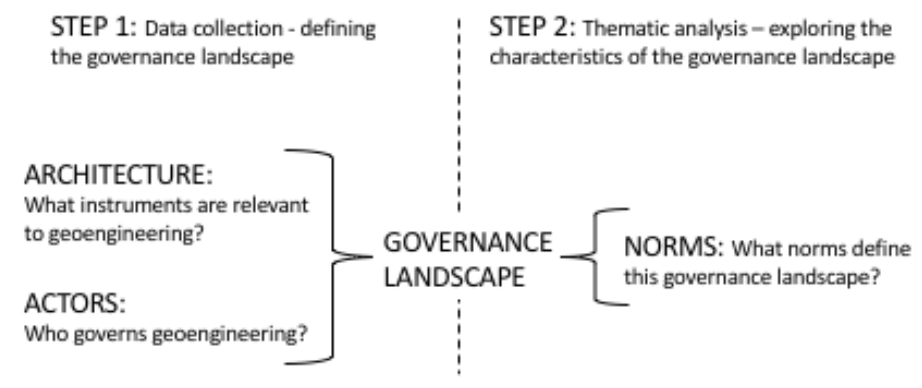




\section{University Library}

\section{- M M N E R VA A gateway to Melbourne's research publications}

Minerva Access is the Institutional Repository of The University of Melbourne

Author/s:

Talberg, A;Christoff, P;Thomas, S;Karoly, D

Title:

Geoengineering governance-by-default: an earth system governance perspective

Date:

2018-04-01

Citation:

Talberg, A., Christoff, P., Thomas, S. \& Karoly, D. (2018). Geoengineering governance-bydefault: an earth system governance perspective. INTERNATIONAL ENVIRONMENTAL AGREEMENTS-POLITICS LAW AND ECONOMICS, 18 (2), pp.229-253. https:// doi.org/10.1007/s10784-017-9374-9.

Persistent Link:

http://hdl.handle.net/11343/283017 